\title{
In vitro effects of fetal rat cerebrospinal fluid on viability and neuronal differentiation of PC12 cells
}

\author{
Mohammad Nabiuni ${ }^{1}$, Javad Rasouli ${ }^{1}$, Kazem Parivar ${ }^{2}$, Homa M Kochesfehani ${ }^{1}$, Saeid Irian $^{1}$ and Jaleel A Miyan ${ }^{3 *}$
}

\begin{abstract}
Background: Fetal cerebrospinal fluid (CSF) contains many neurotrophic and growth factors and has been shown to be capable of supporting viability, proliferation and differentiation of primary cortical progenitor cells. Rat pheochromocytoma PC12 cells have been widely used as an in vitro model of neuronal differentiation since they differentiate into sympathetic neuron-like cells in response to growth factors. This study aimed to establish whether PC12 cells were responsive to fetal CSF and therefore whether they might be used to investigate CSF physiology in a stable cell line lacking the time-specific response patterns of primary cells previously described.
\end{abstract}

Methods: In vitro assays of viability, proliferation and differentiation were carried out after incubation of PC12 cells in media with and without addition of fetal rat CSF. An MTT tetrazolium assay was used to assess cell viability and/ or cell proliferation. Expression of neural differentiation markers (MAP-2 and $\beta$-III tubulin) was determined by immunocytochemistry. Formation and growth of neurites was measured by image analysis.

Results: PC12 cells differentiate into neuronal cell types when exposed to bFGF. Viability and cell proliferation of PC12 cells cultured in CSF-supplemented medium from E18 rat fetuses were significantly elevated relative to the control group. Neuronal-like outgrowths from cells appeared following the application of bFGF or CSF from E17 and E19 fetuses but not E18 or E20 CSF. Beta-III tubulin was expressed in PC12 cells cultured in any media except that supplemented with E18 CSF. MAP-2 expression was found in control cultures and in those with E17 and E19 CSF. MAP2 was located in neurites except in E17 CSF when the whole cell was positive.

Conclusions: Fetal rat CSF supports viability and stimulates proliferation and neurogenic differentiation of PC12 cells in an age-dependent way, suggesting that CSF composition changes with age. This feature may be important in vivo for the promotion of normal brain development. There were significant differences in the effects on PC12 cells compared to primary cortical cells. This suggests there is an interaction in vivo between developmental stage of cells and the composition of CSF. The data presented here support an important, perhaps driving role for CSF composition, specifically neurotrophic factors, in neuronal survival, proliferation and differentiation. The effects of CSF on PC12 cells can thus be used to further investigate the role of CSF in driving development without the confounding issues of using primary cells.

Keywords: Cerebrospinal fluid, PC12 cells, Neuronal differentiation, Fetal rat

\section{Background}

The central nervous system develops around a fluid filled tube, the neural tube. Initially the tube forms around amniotic fluid which is then modified by secretions from a structure in the mesencephalon which transports blood components into the neural tube fluid [1]. This has been shown to form a powerful growth medium, called neural

\footnotetext{
* Correspondence: j.miyan@manchester.ac.uk

${ }^{3}$ Faculty of Life sciences, The University of Manchester, AV Hill Building,

Oxford Road, Manchester M13 9PT, UK

Full list of author information is available at the end of the article
}

tube fluid, or embryonic cerebrospinal fluid (ECSF), for neural stem cells, stimulating proliferation and differentiation in the developing brain stem and spinal cord [2-5]. The cerebral cortex develops much later, the initiation of which coincides with a change in the fluid source to the choroid plexus (CP) as well as an increase in fluid volume and a consequential need for exit from the tube and drainage [6,7]. Subsequently, cerebrospinal fluid (CSF) is secreted by the $\mathrm{CP}$, highly vascularised secretory epithelial structures in the lateral, third and fourth ventricles. During development CSF is rich in protein in contrast to 
the low protein content in normal adults [8,9]. It is secreted from the initial stages of cortical development and continues to be secreted for the entire life of the individual [10]. Previously, CSF was considered to be a fluid with simple physiological and mechanical functions, but it is becoming increasingly clear that CSF plays critical roles in complicated brain physiology, most especially during development, driving the functions of neural stem cells [2,11-19]. Abnormalities in the CSF system or CSF composition are associated with distinct neurological conditions and global developmental defects/deficiencies [20-26].

CSF is the major element forming the external environment for germinal matrix, stem and progenitor cells of the developing cortex, containing a high concentration of cytokines, growth factors and other proteins secreted by the choroid plexus, and which acts as a growth medium for brain development [1,12,27-29]. Although there is some discussion about the timing of formation and the effectiveness of the different barrier systems within the brain, it is accepted that the ependymal layer forms during late cortical development and that neural stem cells are thus in direct contact with CSF during most of the developmental period [30-33]. The path that CSF follows is a one-way flow from the lateral ventricle, through the third ventricle into the cerebral aqueduct to enter the fourth ventricle where it exits the brain into the surrounding subarachnoid space. The fluid then drains via arachnoid villi into the superior sagittal sinus and/or facial lymphatics [6,34-39], although the latter route may not be present until late in development, in the post natal brain [37]. During this process CSF carries signals derived from different sites within the flow pathway to downstream targets [40]. Previous studies have shown that an obstruction in the fluid pathway results in fluid composition changes that arrest cortical development through a cell cycle blockage $[23,24]$. This was shown to be due to inhibition of 10 -formyl tetrahydrofolate dehydrogenase secretion from cells in the ventricular zone [26]. CSF from different ages of normal fetal development was shown to affect proliferation of primary cortical cells in an age-dependent manner [19]. Because the data also showed an age-dependent response of primary cells, we have now investigated the effect of ECSF on in vitro cultures of the PC12 cell line.

PC12 cells are frequently used as an in vitro model for neuronal differentiation. These cells differentiate into dopaminergic neurons when cultured with certain growth factors, including nerve growth factor (NGF), basic fibroblastic growth factor (b-FGF), insulin growth factor-I (IGF-I), glial cell line-derived neurotrophic factor (GDNF), epidermal growth factor (EGF) and transforming growth factor- $\alpha$ (TGF- $\alpha$ ) [41-44]. It seemed reasonable to use these cells to investigate the effects of developmental CSF without the confounding effects of age-dependent responses of primary cells. The aim of the present study was to investigate the effects of prenatal CSF from various gestational ages on the survival, proliferation and differentiation of PC12 cells.

\section{Methods}

\section{Animals}

Wistar rats were bred in house in the research facility of the Department of Biology, Tarbiat Moallem University following ethical review of the project by the animal use committees of both The University of Manchester and Tarbiat Moallem University. They were kept in large rat boxes at constant temperature and 12hour light/dark cycle with free access to food and water. Individual male and female rats were paired in mating cages and checked regularly for the presence of a vaginal plug which was taken as an indication of successful mating and the day noted as embryonic day 0 (E0). Embryonic age was calculated from that day. At a particular time point pregnant dams were euthanized by cervical dislocation, the uterus rapidly removed onto ice and fetuses dissected out onto ice. Each pregnant dam usually produced between 10-15 fetuses.

\section{Collection of CSF samples}

CSF was collected from the cisterna magna of rat fetuses at E17, E18, E19, and E20 using glass micropipettes and capillary action without aspiration. Aspiration invariably resulted in bleeding and contamination of the samples. Fetuses were positioned with heads flexed down onto the chest to allow penetration into the cisternal cavity through the skin and underlying muscle. Samples containing undesirable blood contamination, visualised as a pink colour in the fluid, caused by damaging a blood vessel within the cisternal cavity, were discarded. All samples were collected into sterile microtubes and centrifuged at 14,000 rpm to remove cells or debris from the fluid, and the supernatant was transferred into another sterile tube. These samples were stored at $-80^{\circ} \mathrm{C}$ until use. The volume of CSF collected from each fetus by this method was between 5 and $50 \mu \mathrm{l}$ and samples were pooled for each experiment. At least three litters provided six independent pooled samples (half litter per pooled sample) for each age of CSF tested.

\section{Total protein analysis}

Total protein concentration in each pooled CSF sample was determined by the Bio-Rad protein assay (Bio-Rad Laboratories, Hercules, CA, USA), based on the Bradford dye procedure. The absorbance of samples was measured at $595 \mathrm{~nm}$ wavelength. Each pooled sample was analysed for each age tested.

\section{PC12 cell culture and in vitro tests}

PC12 cells were cultured in RPMI1640 medium (Gibco, Life Technologies Corporation) containing $10 \%$ fetal 


\section{Total Protein}

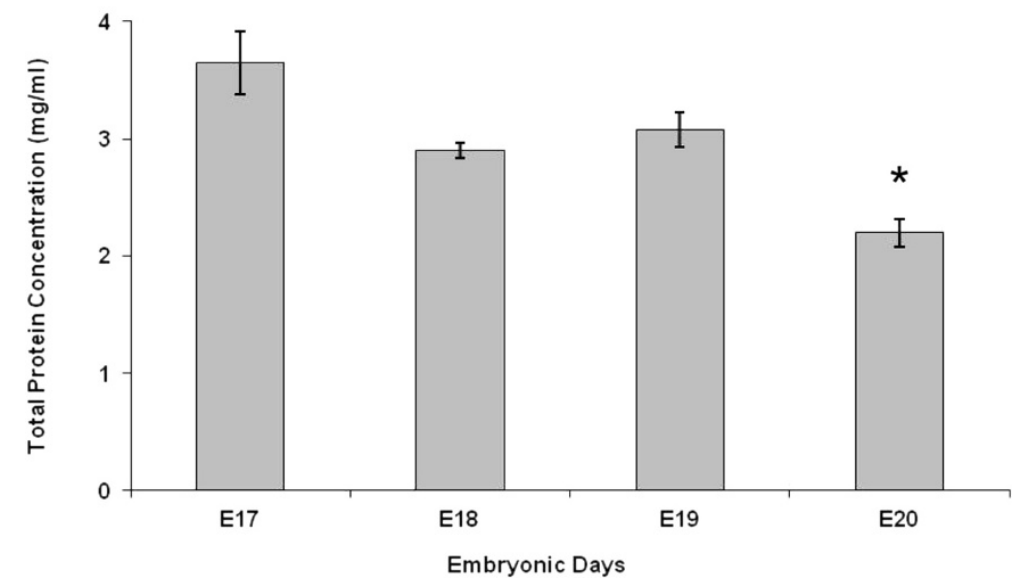

Figure 1 Total protein content of fetal rat CSF. Histogram of total protein concentration in pooled samples of cerebrospinal fluid (CSF) from rat fetuses at days E17 to E20. The data shown are mean \pm SEM, $n=5$ at each age. There was a significant difference between E17 and E20 ECSF protein content $p<0.05)$.

bovine serum, $100 \mathrm{U} / \mathrm{ml}$ penicillin and $100 \mathrm{mg} / \mathrm{ml}$ streptomycin. The cultures were kept in a humidified incubator with $5 \% \mathrm{CO}_{2}$ and maintained at $37^{\circ} \mathrm{C} . \mathrm{PC} 12$ culture medium was refreshed in a $2 / 3$ ratio every 2 days. For tests, $100 \mu \mathrm{l}$ of cells at $4 \times 10^{4}$ cells $/ \mathrm{ml}(4000$ cells/well) in RPMI1640 medium were plated into poly-D-lysine coated 96-well plates and cultured in a RPMI1640 medium without serum for 24 hours and then supplemented with CSF $(\mathrm{E} 17-20)(10 \% \mathrm{v} / \mathrm{v})$ or bFGF $(10 \mathrm{ng} / \mathrm{ml})$ for 7 days. bFGF was used as a positive promoter of PC12 cell proliferation and differentiation into neuronal phenotypes to compare to the effects of CSF. After one week, cells were photographed and then prepared for morphological examination and immunocytochemical staining. Three wells were used for each pooled CSF sample giving a total of at least nine wells per CSF age tested. An additional three wells per pooled sample were used for the MTT assay. Cells were photographed at the end of each experiment using phase

\section{MTT Assay}

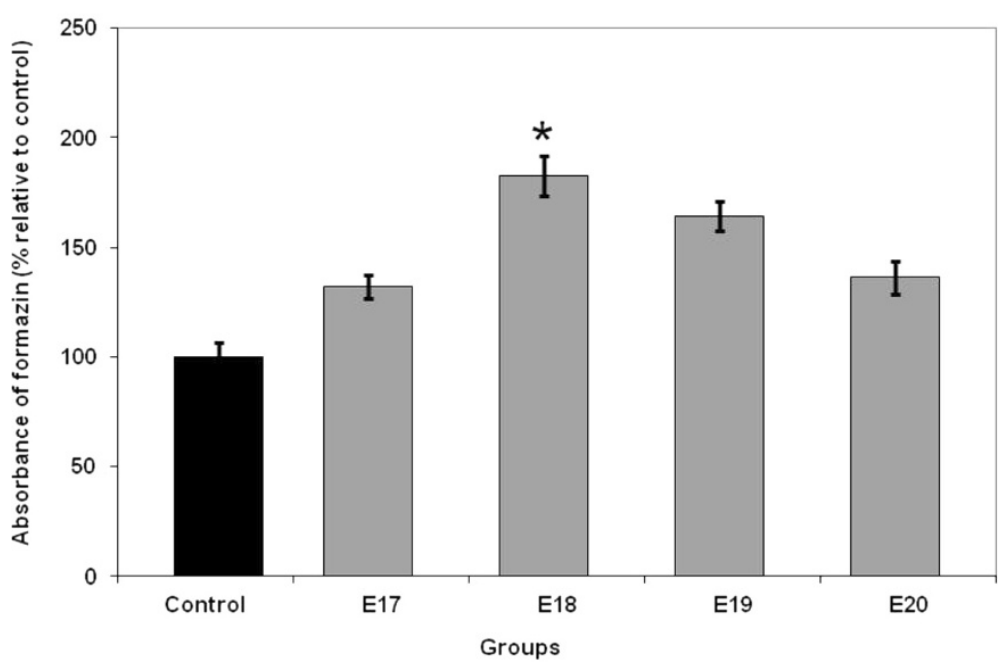

Figure 2 Survival and/or proliferation of PC12 cells after culture with fetal rat CSF. Reduction of MTT (3-(4,5-Dimethylthiazol-2-yl)-2,5diphenyltetrazolium bromide) measured colourimetrically by the absorbance of formazan product. Cells were treated with CSF at different gestational ages (E17-E20) and measured after 7 days in culture. Results are expressed as a percentage of control levels (cultures without added CSF). All cultures with added CSF had higher viability and this was significant with E18 CSF. Data are mean \pm SEM, $\mathrm{n}=9$, *; $p<0.05$ compared to controls. 
contrast optics. Cells were then fixed in $4 \%$ paraformaldehyde and immunostained for $\beta$-tubulin and MAP2 using monoclonal antibodies (Abcam, Cambridge, UK), visualised with FITC conjugated goat-anti mouse secondary antibodies and photographed using fluorescence microscopy. Controls were stained with vehicle solution without the primary antibody. At least six wells were stained for both $\beta$-tubulin and MAP2 expression and at least three wells were used as negative controls.

\section{Measurement of neurite length}

For each culture condition, cells in individual wells were photographed with phase-contrast optics (Olympus, Tokyo, Japan) to visualize outgrowths from the cells. Measurements were made using Image J software (NIH). A neurite was counted when a cellular process was longer than the diameter of the cell body. The average length of neurites was calculated from measurements of 10 cells in each of 6 wells for each age of CSF tested.

\section{Cell viability assay}

Cell viability and/or proliferation was quantitatively determined by the MTT method using a colorimetric assay at the end of 7 days in control medium or medium containing CSF or bFGF. MTT (3-(4,5-Dimethylthiazol-2-yl)-2,5diphenyltetrazolium bromide), is a yellow tetrazolium dye that responds to metabolic activity. Reductase enzymes in living cells reduce MTT from a pale yellow colour to dark blue formazan crystals. Cells were plated at 4000 cells per well as described above. In separate experiments cells were
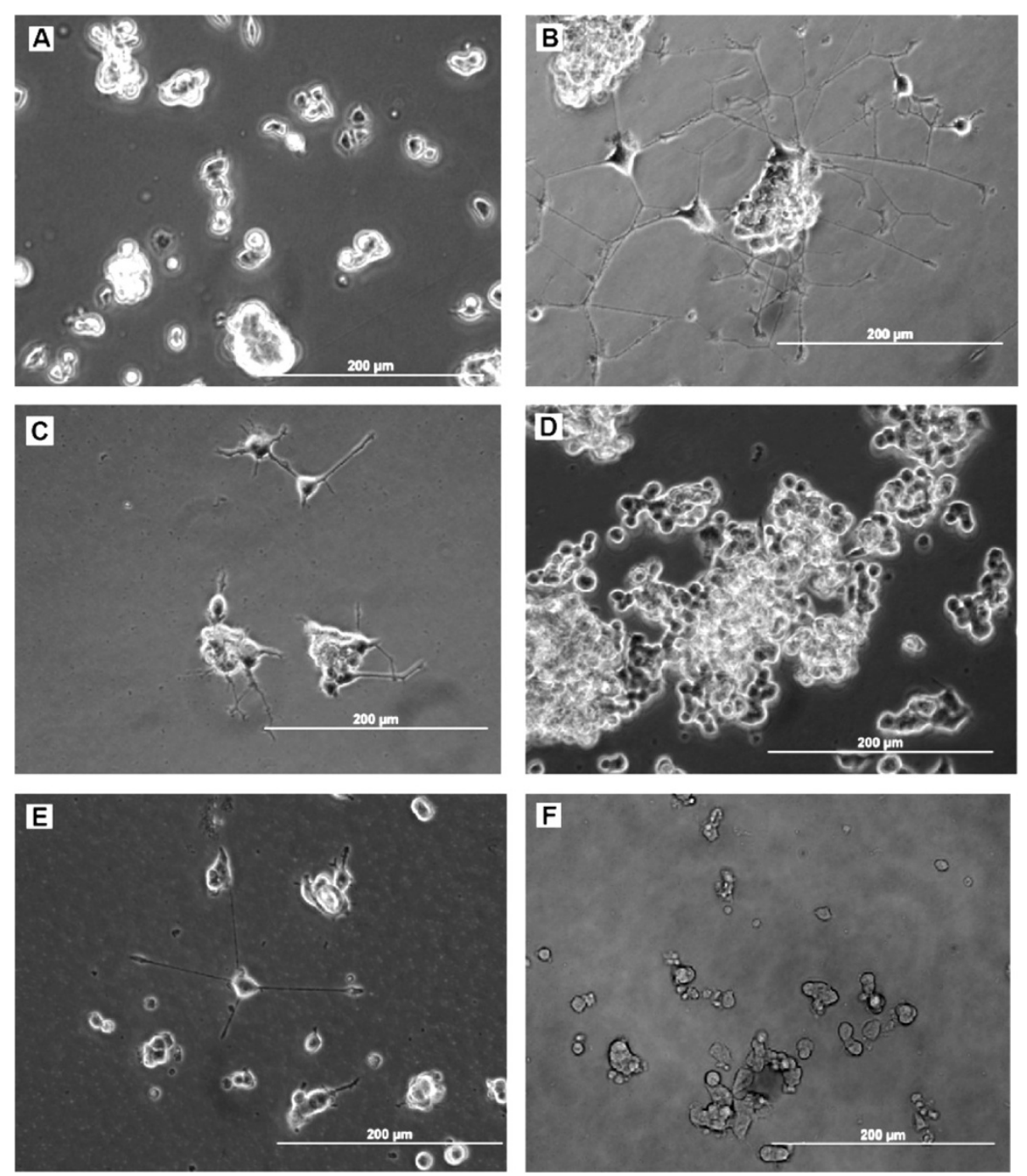

Figure 3 PC12 cells after 7 days in culture photographed with phase-contrast optics. A: control culture, B: culture with b-FGF, C: culture with added CSF-E17, D: with CSF-E18, E: with CSF-E19 and F: with CSF-E20. PC12 cells cultured with ECSF from E17 and E19, and with b-FGF showed neurite outgrowth and morphological differentiation, whereas cells cultured with E-CSF from E18, E20, and the control group (A) did not show any significant differentiation. 
plated at 2000 cells per well with no difference in proliferation or differentiation results (data not shown). At $24 \mathrm{~h}$, prior to addition of CSF or bFGF control plates were analysed for starting number of cells. Experimental and control media plates were left for a further 7 days and then analysed for proliferation. Wells were incubated with MTT (5 mg/mL in PBS) for $3 \mathrm{~h}$ at $37^{\circ} \mathrm{C}$. In order to make formazan crystals soluble, $0.04 \mathrm{~N} \mathrm{HCl}$, prepared in isopropranolol, was added. The absorbance of the formazan product was determined at a wavelength of $570 \mathrm{~nm}$ using a plate reader.

\section{Immunocytochemistry}

For immunocytochemistry, after three washes with PBS for $5 \mathrm{~min}$, cells were fixed in $4 \%$ paraformaldehyde in PBS for $15 \mathrm{~min}$, permeabilized with $0.1 \%$ Triton X-100 for $30 \mathrm{~min}$ at room temperature and subsequently blocked with 5\% BSA in TPBS (Tween 20 in PBS) for $1 \mathrm{~h}$ at room temperature. Cells were incubated at $4{ }^{\circ} \mathrm{C}$ overnight in the presence of either anti-beta III tubulin mAb (1:50 dilution) or anti-MAP2 mAb (1:50 dilution). The following day, after three washes with TPBS, FITCconjugated goat anti-mouse IgG (1:250 dilution; SigmaAldrich, Poole, UK) was added at room temperature for $1 \mathrm{hr}$. Cells were then washed and cellular nuclei were counterstained with propidium iodide (Sigma-Aldrich). Photomicrographs were taken with a florescence microscope (Olympus, Tokyo, Japan).

\section{Statistical analysis}

All values are expressed as mean \pm standard error of the mean (SEM). Statistical analysis was performed using the one-way ANOVA and Kruskal-Wallis test, and significance was accepted for $p$ values of $<0.05$.
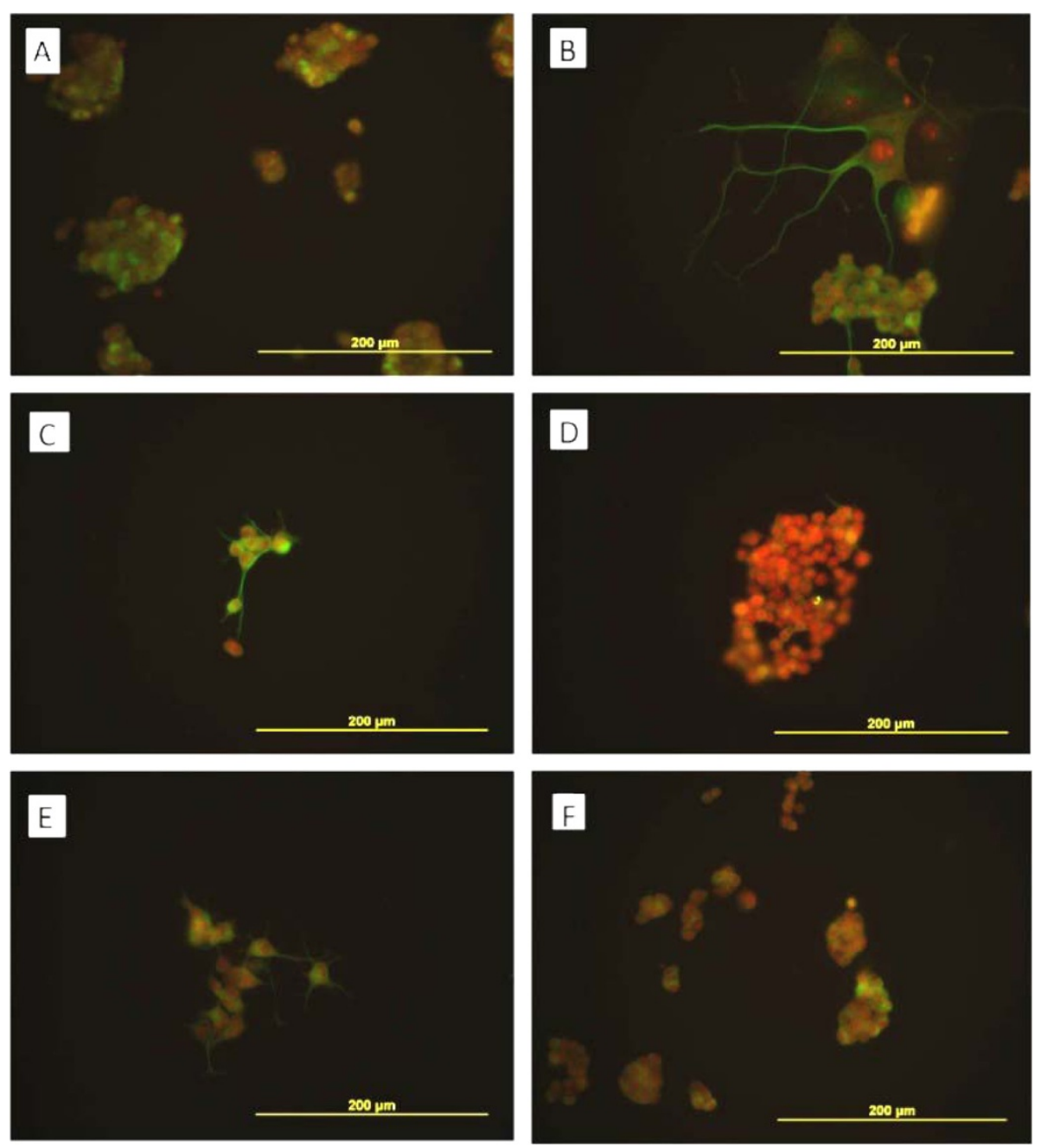

Figure 4 Beta III tubulin expression (green) in PC12 cells counterstained with propidium iodide (red). Beta III tubulin is expressed in PC12 cells cultured in normal media (A), media with b-FGF $(10 \mathrm{ng} / \mathrm{ml})(\mathbf{B})$, or with E-CSF from E17 (C), E19 (E) or E20 (F) but not in cells cultured with E18 CSF (D). 


\section{Results}

Total protein concentration

CSF of rat fetuses aged E17 had a mean total protein concentration of $3.65 \pm 0.26 \mathrm{mg} / \mathrm{ml}$, which was significantly higher than that of E20 CSF $(2.19 \pm 0.12 \mathrm{mg} / \mathrm{ml}, p<0.05$, Figure 1). Protein concentrations at E18 and E19 were intermediate at 2.90 and $3.08 \mathrm{mg} / \mathrm{ml}$, respectively.

\section{Effects of embryonic CSF (ECSF) on the viability and/or proliferation of PC12 cells}

Figure 2 shows the absorbance of formazan produced by cells treated for 7 days in culture with CSF from different gestational ages. Compared to controls, a higher absorbance $(p<0.05)$ was obtained when cells were cultured with the medium supplemented with CSF of any age indicating greater viability of cells compared with that in media alone. E18 CSF gave a significant increase in viability over that seen in media alone which fits with our previous data from primary cortical cells where E18 and E19 CSF gave increased proliferation of E20 cells [24]. For the PC12 cells cultured with CSF, there was greater clumping of cells suggestive of greater stimulation of cell-cell adhesion rather than cell-substrate adhesion (Figures 3, 4 and 5). This requires further investigation.

\section{CSF induces neuronal differentiation in PC12 cells}

Phase-contrast images of cultured PC12 cells are shown in Figure 3. Compared to control medium (Figure 3A), enhanced neurite outgrowth and morphological differentiation occurred with cells incubated with bFGF (Figure 3B), and in the presence of the medium supplemented with CSF-E17 (Figure 3C) and E19 (Figure 3E). Little or no morphological differentiation was detected in the control medium (Figure 3A), with CSF-E18 (Figure 3D), or with CSF-E20 (Figure 3F). However, with CSF-E18, PC12 cells showed more proliferation. Clumping of cells was seen
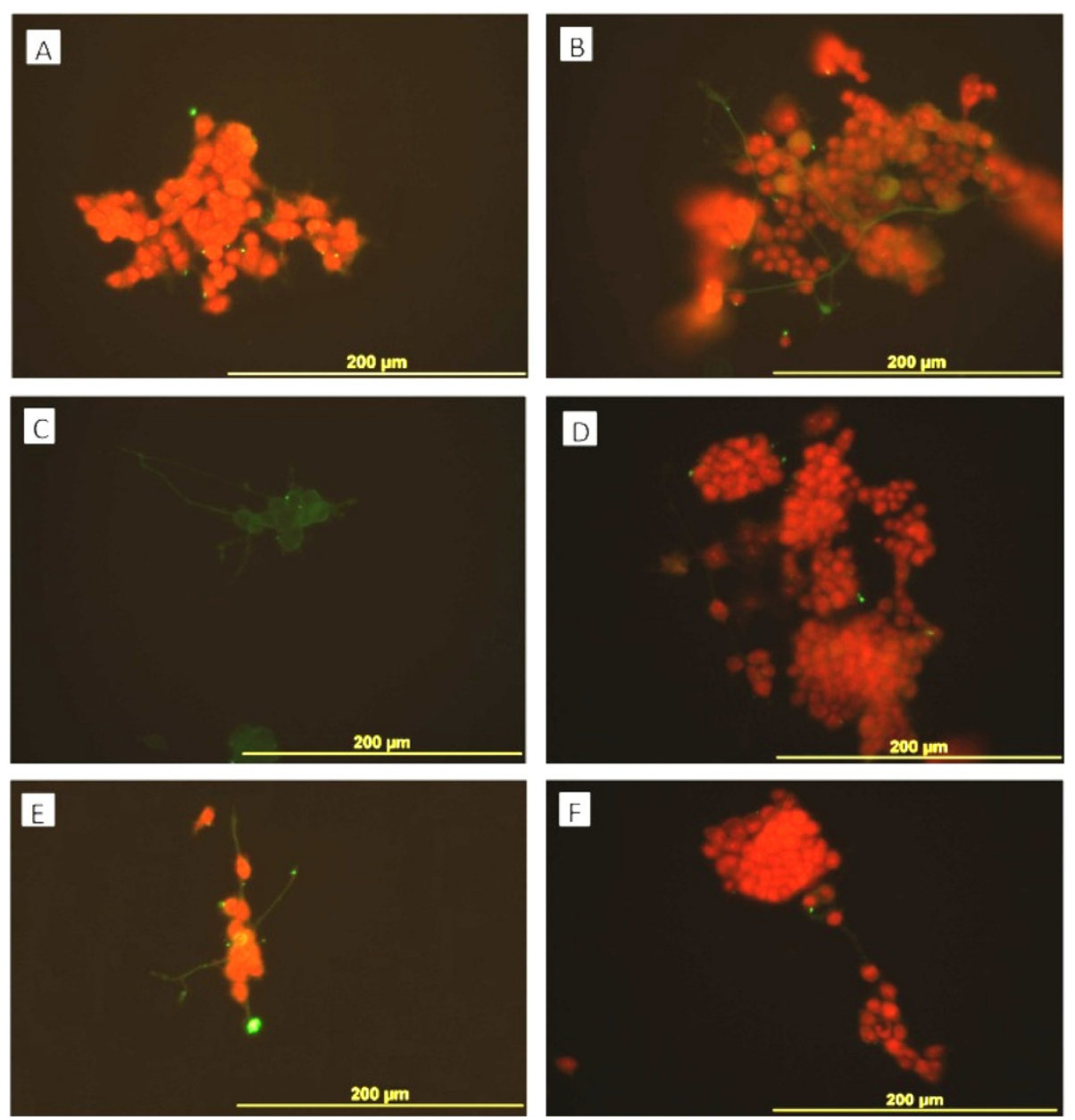

Figure 5 MAP2 expression (green) in PC12 cells counterstained with propidium iodide (red). MAP2 expression is shown in PC12 cells cultured with CSF supplemented medium from E17 (C), in the neurites of cells in E19 (E) and b-FGF (10 ng/ml) (B) but not in cells cultured with CSF from E18 (D), E20 $(\mathbf{F})$, or in control media $(\mathbf{A})$. 
with CSF and also with b-FGF, suggestive of cell-cell interactions rather than "simple" clumping due to a lack of initial separation of cells in plating. We utilized the growth factor bFGF $(10 \mathrm{ng} / \mathrm{ml})$ to compare its effects on differentiation with those of ECSF treatment.

\section{Immunocytochemical characteristics of differentiated PC12 cells}

We found beta III tubulin expression in PC12 cells grown in control media as well as in media supplemented with E17, E19 and E20 CSF but not in E18 CSF (Figure 4) By contrast we found little evidence of MAP2 expression in PC12 cells (Figure 5) except in the neurites of cells cultured with bFGF or CSF from E17 or E19 but not in control media or in CSF from E18 or E20. Interestingly, cells cultured in E17 CSF showed expression in neurites and in their cell bodies (Figure 5c).

\section{Measurement of neurite outgrowth}

The average neurite outgrowth of cells was significantly greater than controls when cultured in the presence of b-FGF $(p<0.001)$, or CSF from E17 $(p<0.01)$ and E19 $(p<0.001)$ for 7 days (Figure 6). It was not increased over controls in CSF from E18 or E20 though there was a non-significant increase in E18 CSF. In addition, and as shown in Figure 3, the density and length of neurites was much greater in b-FGF treated cells than in CSF (E17 and E19) treated cells.

\section{Discussion}

The present study has shown that CSF from rat fetuses at different developmental ages (E17-E20) has a high protein concentration of around $3 \mathrm{mg} / \mathrm{ml}$ that declined to $2 \mathrm{mg} / \mathrm{ml}$ by E20. CSF when added to cultures of PC12 cells had different effects on survival, proliferation and neuronal differentiation depending on age. In contrast to the control groups, samples of CSF at all ages tested, gave a greater formazan absorbance reading indicating improved cell survival and/or proliferation. This was only significant with E18 CSF indicating a greater effect of CSF at this age. Interestingly we previously showed a greater proliferation of primary rat cortical cells in both E19 and E18 CSF over both controls and E17 or E20 CSF [19]. The significant and most surprising result in the current study is the failure of PC12 cells to respond to E18 CSF with any measurable differentiation in either the MAP2 or beta III tubulin study, even though E18 CSF stimulated greater proliferation. These findings would fit with a three stage process, initial production of preplate neurons at E17, high rates of proliferation within the ventricular zone at E18, and migration of immature neurons and differentiation of migrated neurons within the cortical plate over E18-E20 [45,46]. The difference between the effects of PC12 cells and primary cortical cells indicate a possible difference between the preprogrammed development of the in vivo neural stem/ progenitor cells and the driving force of CSF composition in isolation.

In our experiments, we used cisternal CSF which is likely to contain both proliferation, differentiation and migration signals as it contains all the additions to CSF that are made as the fluid passes through the ventricles. It would of great value to test ventricular CSF and compare its effects since our previous arguments suggest that this may only contain proliferation and possibly differentiation signals but not migration signals $[6,7,23,25]$. Thus, one outcome of this study is that the parallel use of primary cortical cells and PC12 cells can help to

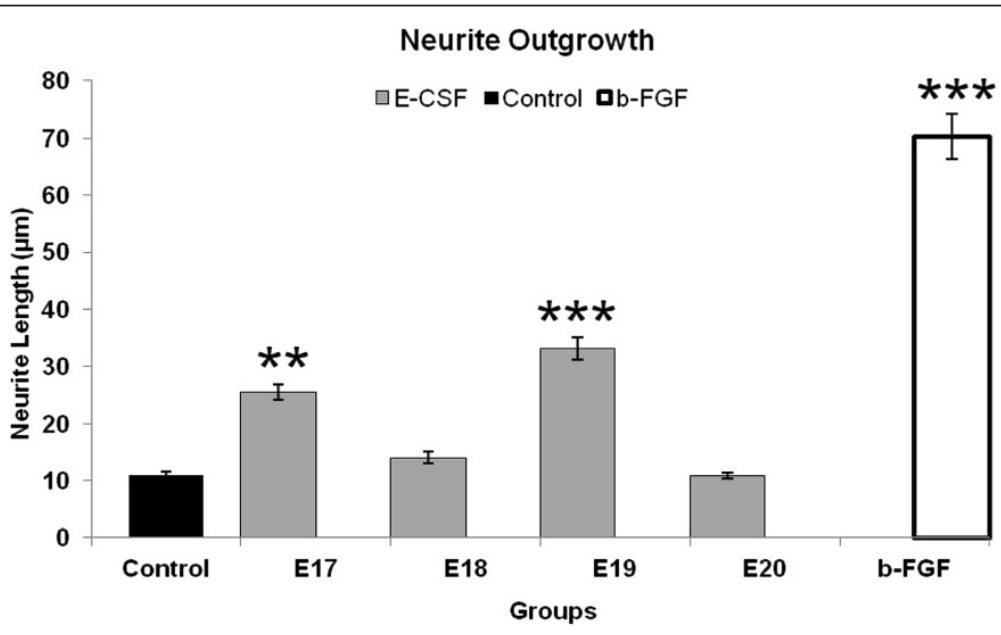

Figure 6 Neurite growth in PC12 cell cultures. Length of neurites of PC12 cells cultured with E-CSF-supplemented medium and b-FGF (10 ng/ ml). PC12 cells were grown on 96-well cell culture plates for 7 days. Neurite length was measured as described. Data are mean $\pm S E M, n=9,{ }^{* *}$; $p<0.01$ and ${ }^{* * *} ; p<0.001$ compared to control culture. 
elucidate the varying roles of developmental timedependent programming of cells versus the contributions made by the changes in CSF composition with age.

Almost $75 \%$ of CSF is secreted in vivo by the CP located in the lateral ventricles with an additional $10 \%$ and $5 \%$ secreted by the $\mathrm{CP}$ in the third and fourth ventricles respectively [47,48]. Additional components are added to the ventricular CSF from the interstitial fluid of the brain parenchyma and from specific organs including the circumventricular organs. The most studied of these is the subcommissural organ which has been shown to be vital for particular physiological functions as well as keeping the CSF pathways open [49-54]. Recent research demonstrates wa significant, if not major role for CSF in the survival, proliferation, migration and differentiation of neural stem/progenitor cells $[5,11,12,19,55]$. Where problems exist in the CSF system, whether in flow or composition, this developmental program is adversely affected in ways that interfere in normal development $[4,20,34,49,56-61]$. The most critical constituents of CSF are its protein components, the quality and quantity of which change during CNS development [62-66]. About 20\% of CSF proteins are derived from CNS, neurons, glial and leptomeningeal cells, whereas the remaining $80 \%$ originate from the blood or are synthesized by the CP $[30,67]$. The CP synthesizes and secretes many proteins, including various growth factors and neurotrophic factors into the CSF $[30,67]$. These proteins are carried by CSF bulk flow and provide the developing brain with trophic support for cell survival and neurogenesis [68]. The utilization of neutralizing antibodies against growth factors in CSF showed that blocking of FGF2 in chick ECSF reduces cell proliferation, cell viability and neurogenesis in chick neuroepithelium [69], while the thickness of the neuroepithelium and neuronal precursor proliferation decreased after anti-NGF antibody was injected into the fluid cavity of developing chick brain [70,71]. The current study provides a parallel cell line-based analysis system to that of primary brain cells to investigate the role of CSF. This approach is important as the interaction between primary cell age and CSF age has already been demonstrated [19] while the isolated effect of CSF on a cell line might not expose all the interactions. The in vitro survival, proliferation and neuronal differentiation of $\mathrm{PC} 12$ cells are dependent on certain growth factors which must also be present in the CSF to elicit the effects observed in this study. The evidence from previous studies indicates that understanding the detailed role of CSF in development, function and pathophysiology of the brain will be one key productive area to promote normal development and to develop strategies and treatments to prevent abnormal development and neuropathological conditions. Isolating CSF components responsible for these different effects can be achieved using the parallel approach we propose. In our recent work we have described a unique folate handling system serving the developing cerebral cortex that operates through the CSF [26]. Obstruction to CSF flow or drainage results in a failure of cortical cells to release 10-formyl tetrahydrofolate, which we believe acts as a folate binding and transporter protein in CSF, and to an arrest in cell cycle and consequential deficient cortical development $[23,24,26]$. Folate supply to the cerebral cortex can be affected independently of supply to the rest of the CNS and body and result in various cerebral folate deficiencies underlying a variety of neurological conditions that can be alleviated by specific folate supplements $[20,22,26,57,61,72-81]$. In addition to this folate supply to the developing cortex, there is a complex mix of growth factors and other important proteins in developmental CSF that are affected by CSF drainage and obstruction which remain to be tested for direct effects on the process of cortical development (unpublished data).

\section{Conclusions}

This study has shown that CSF from fetal rat brains of different gestational ages can promote the survival, proliferation and differentiation of $\mathrm{PC} 12$ cells in an age dependent manner. Significant differences exist between the response of PC12 cells compared to primary fetal cortical cells perhaps indicating an interaction between the programming of primary cells and age-dependent composition differences in CSF in the latter case. The use of PC12 cells in future studies of CSF physiology may therefore allow the identification of CSF factors effecting cell physiology in isolation of primary cell, in vivo programming.

\section{Abbreviations}

ANOVA: analysis of variance; BSA: Bovine serum albumin; CNS: Central Nervous System; CP: choroid plexus; CSF: cerebrospinal fluid; ECSF: Embryonic cerebrospinal Fluid; FITC: fluorescein isothiocyanate; IgG: Immunoglobulin G; MAP: mitogen-activated protein; MTT: 3-(4,5-dimethylthiazol-2-yl)-2,5diphenyltetrazolium bromide; PBS: phosphate buffered saline; PC: pheochromocytoma.

\section{Competing interests}

None of the authors have any competing interests.

\section{Acknowledgements}

Gratitude for research support is expressed to the Department of Biology, Faculty of Science of Tarbiat Moalem University, Tehran, Iran. We are extremely grateful to Dr M. Soleimani (Tarbiat Modares University, Iran) for providing us with antibodies. We thank Dr Hazel Jones for comments on the MS.

\section{Author details}

${ }^{1}$ Department of Biology, Tarbiat Moallem University, Tehran, Iran. ${ }^{2}$ Department of Biology, Science and Research Branch, Islamic Azad University, Tehran, Iran. ${ }^{3}$ Faculty of Life sciences, The University of Manchester, AV Hill Building, Oxford Road, Manchester M13 9PT, UK.

\section{Authors' contributions}

MN and JAM conceived and designed the experiments. JR, KP, HMK and SI carried out the experiments. All authors were involved in writing and editing the manuscript and preparation of figures. All authors have read and approved the final version of the manuscript. 
Received: 30 November 2011 Accepted: 11 April 2012

Published: 11 April 2012

\section{References}

1. Parvas M, Parada C, Bueno D: A blood-CSF barrier function controls embryonic CSF protein composition and homeostasis during early CNS development. Dev Biol 2008, 321:51-63.

2. Gato A, Moro JA, Alonso Ml, Bueno D, De La Mano A, Martin C: Embryonic cerebrospinal fluid regulates neuroepithelial survival, proliferation, and neurogenesis in chick embryos. Anat Rec A Discov Mol Cell Evol Biol 2005, 284A:475-484

3. Parada C, Gato A, Bueno D: All-trans retinol and retinol-binding protein from embryonic cerebrospinal fluid exhibit dynamic behaviour during early central nervous system development. NeuroReport 2008, 19:945-950.

4. Gato A, Desmond ME: Why the embryo still matters: CSF and the neuroepithelium as interdependent regulators of embryonic brain growth, morphogenesis and histiogenesis. Dev Biol 2009, 327:263-272.

5. Martin C, Alonso Ml, Santiago C, Moro JA, De la Mano A, Carretero R, Gato A: Early embryonic brain development in rats requires the trophic influence of cerebrospinal fluid. Int I Dev Neurosci 2009, 27:733-740.

6. Miyan JA, Nabiyouni M, Zendah M: Development of the brain: a vital role for cerebrospinal fluid. Can J Physiol Pharmacol 2003, 81:317-328.

7. Pourghasem M, Mashayekhi F, Bannister CM, Miyan J: Changes in the csf fluid pathways in the developing rat fetus with early onset hydrocephalus. Eur J Pediatr Surg 2001, 11(Suppl 1):S10-S13.

8. Nabiyouni M, Storey C, Owen-Lynch J, Miyan J: Proteomics study of CSF composition in the developing H-Tx rat. Cerebrospinal Fluid Res 2004, 1 : S29.

9. Parada C, Gato A, Aparicio M, Bueno D: Proteome analysis of chick embryonic cerebrospinal fluid. Proteomics 2006, 6:312-320.

10. Mollanji R, Papaiconomou C, Boulton M, Midha R, Johnston M: Comparison of cerebrospinal fluid transport in fetal and adult sheep. Am J Physiol Regul Integr Comp Physiol 2001, 281:R1215-R1223.

11. Lehtinen MK, Walsh CA: Neurogenesis at the brain-cerebrospinal fluid interface. Annu Rev Cell Dev Biol 2011, 27:653-679.

12. Lehtinen MK, Zappaterra MW, Chen X, Yang YJ, Hill AD, Lun M, Maynard T, Gonzalez D, Kim S, Ye P, et al: The cerebrospinal fluid provides a proliferative niche for neural progenitor cells. Neuron 2011, 69:893-905.

13. Buddensiek J, Dressel A, Kowalski M, Runge U, Schroeder H, Hermann A, Kirsch M, Storch A, Sabolek M: Cerebrospinal fluid promotes survival and astroglial differentiation of adult human neural progenitor cells but inhibits proliferation and neuronal differentiation. BMC Neurosci 2010, 11:48

14. Buddensiek J, Dressel A, Kowalski M, Storch A, Sabolek M: Adult cerebrospinal fluid inhibits neurogenesis but facilitates gliogenesis from fetal rat neural stem cells. J Neurosci Res 2009, 87:3054-3066.

15. Sawamoto K, Wichterle H, Gonzalez-Perez O, Cholfin JA, Yamada M, Spassky N, Murcia NS, Garcia-Verdugo JM, Marin O, Rubenstein JL, et al: New neurons follow the flow of cerebrospinal fluid in the adult brain. Science 2006, 311:629-632

16. Vigh B, Silva MJ Manzano e, Frank CL, Vincze C, Czirok SJ, Szabo A, Lukats A, Szel A: The system of cerebrospinal fluid-contacting neurons. Its supposed role in the nonsynaptic signal transmission of the brain. Histol Histopathol 2004, 19:607-628.

17. Xia $Y X, \mid k e d a T, X i a X Y$, Ikenoue T: Differential neurotrophin levels in cerebrospinal fluid and their changes during development in newborn rat. Neurosci Lett 2000, 280:220-222

18. Rodriguez EM: The cerebrospinal fluid as a pathway in neuroendocrine integration. J Endocrinol 1976, 71:407-443.

19. Miyan JA, Zendah M, Mashayekhi F, Owen-Lynch PJ: Cerebrospinal fluid supports viability and proliferation of cortical cells in vitro, mirroring in vivo development. Cerebrospinal Fluid Res 2006, 3:2.

20. Frye RE, Sequeira JM, Quadros EV, James SJ, Rossignol DA: Cerebral folate receptor autoantibodies in autism spectrum disorder. Mol Psychiatry 2012, Epub ahead of print

21. Main PA, Angley MT, Thomas P, O'Doherty CE, Fenech M: Folate and methionine metabolism in autism: a systematic review. Am J Clin Nutr 2010, 91:1598-1620.

22. Moretti P, Sahoo T, Hyland K, Bottiglieri T, Peters S, del Gaudio D, Roa B, Curry S, Zhu H, Finnell RH, et al: Cerebral folate deficiency with developmental delay, autism, and response to folinic acid. Neurology 2005, 64:1088-1090.

23. Mashayekhi F, Draper CE, Bannister CM, Pourghasem M, Owen-Lynch PJ, Miyan JA: Deficient cortical development in the hydrocephalic Texas (H-Tx) rat: a role for CSF. Brain 2002, 125:1859-1874.

24. Owen-Lynch PJ, Draper CE, Mashayekhi F, Bannister CM, Miyan JA: Defective cell cycle control underlies abnormal cortical development in the hydrocephalic Texas rat. Brain 2003, 126:623-631.

25. Bannister CM, Nabiuni M, Zendah M, Mashayekhi F, Miyan JA: Development anomalies of the cerebral hemispheres in spina bifida aperta. In Trends in Spina Bifida Research. Edited by Zesta MR. New York: Nova Science Publishers, Inc; 2005:31-42.

26. Cains S, Shepherd A, Nabiuni M, Owen-Lynch PJ, Miyan J: Addressing a folate imbalance in fetal cerebrospinal fluid can decrease the incidence of congenital hydrocephalus. J Neuropathol Exp Neurol 2009, 68:404-416

27. Salehi Z, Mashayekhi F, Naji M, Pandamooz S: Insulin-like growth factor-1 and insulin-like growth factor binding proteins in cerebrospinal fluid during the development of mouse embryos. J Clin Neurosci 2009, 16: 950-953.

28. Zougman A, Pilch B, Podtelejnikov A, Kiehntopf M, Schnabel C, Kumar C, Mann M: Integrated Analysis of the Cerebrospinal Fluid Peptidome and Proteome. J Proteome Res 2008, 7:386-399.

29. Zappaterra MD, Lisgo SN, Lindsay S, Gygi SP, Walsh CA, Ballif BA: A comparative proteomic analysis of human and rat embryonic cerebrospinal fluid. J Proteome Res 2007, 6:3537-3548.

30. Ek CJ, Dziegielewska KM, Habgood MD, Saunders NR: Barriers in the developing brain and Neurotoxicology. NeuroToxicology 2011, Epub ahead of print.

31. Ek CJ, Wong A, Liddelow SA, Johansson PA, Dziegielewska KM, Saunders NR: Efflux mechanisms at the developing brain barriers: $\mathrm{ABC}$-transporters in the fetal and postnatal rat. Toxicol Lett 2010, 197:51-59.

32. Saunders NR, Habgood MD, Dziegielewska KM: Barrier mechanisms in the brain, I. Adult brain. Clin Exp Pharmacol Physiol 1999, 26:11-19.

33. Saunders NR, Habgood MD, Dziegielewska KM: Barrier mechanisms in the brain, II. Immature brain. Clin Exp Pharmacol Physiol 1999, 26:85-91.

34. Holman DW, Kurtcuoglu V, Grzybowski DM: Cerebrospinal fluid dynamics in the human cranial subarachnoid space: an overlooked mediator of cerebral disease. II. In vitro arachnoid outflow model. J R Soc Interface 2010, 7:1205-1218

35. Gupta S, Soellinger M, Grzybowski DM, Boesiger P, Biddiscombe J, Poulikakos D, Kurtcuoglu V: Cerebrospinal fluid dynamics in the human cranial subarachnoid space: an overlooked mediator of cerebral disease. I. Computational model. J R Soc Interface 2010, 7:1195-1204.

36. Koh L, Nagra G, Johnston M: Properties of the lymphatic cerebrospinal fluid transport system in the rat: impact of elevated intracranial pressure. J Vasc Res 2007, 44:423-432.

37. Koh L, Zakharov A, Nagra G, Armstrong D, Friendship R, Johnston M: Development of cerebrospinal fluid absorption sites in the pig and rat: connections between the subarachnoid space and lymphatic vessels in the olfactory turbinates. Anat Embryol (Berl) 2006, 211:335-344.

38. Koh L, Zakharov A, Johnston M: Integration of the subarachnoid space and lymphatics: is it time to embrace a new concept of cerebrospinal fluid absorption? Cerebrospinal Fluid Res 2005, 2:6.

39. Perez-Figares JM, Jimenez AJ, Rodriguez EM: Subcommissural organ, cerebrospinal fluid circulation, and hydrocephalus. Microsc Res Tech 2001, 52:591-607.

40. Nicholson C: Signals that go with the flow. Trends Neurosci 1999, 22:143-145

41. D'Alessandro R, Meldolesi J: In PC12 cells, expression of neurosecretion and neurite outgrowth are governed by the transcription repressor REST/NRSF. Cell Mol Neurobiol 2010, 30:1295-1302

42. Martin TF, Grishanin RN: PC12 cells as a model for studies of regulated secretion in neuronal and endocrine cells. Methods Cell Biol 2003, 71:267-286

43. Vaudry D, Chen Y, Hsu CM, Eiden LE: PC12 cells as a model to study the neurotrophic activities of PACAP. Ann N Y Acad Sci 2002, 971:491-496.

44. Fujita K, Lazarovici P, Guroff G: Regulation of the differentiation of PC12 pheochromocytoma cells. Environ Health Perspect 1989, 80: 127-142. 
45. Guerrini R, Dobyns WB, Barkovich AJ: Abnormal development of the human cerebral cortex: genetics, functional consequences and treatment options. Trends Neurosci 2008, 31:154-162

46. Rakic P: A century of progress in corticoneurogenesis: from silve impregnation to genetic engineering. Cereb Cortex 2006, 16(Suppl 1): i3-17.

47. Chen RL, Kassem NA, Redzic ZB, Chen CP, Segal MB, Preston JE: Age-related changes in choroid plexus and blood-cerebrospinal fluid barrier function in the sheep. Exp Gerontol 2009, 44:289-296.

48. Redzic ZB, Preston JE, Duncan JA, Chodobski A, SzmydyngerChodobska J: The choroid plexus-cerebrospinal fluid system: from development to aging. Curr Top Dev Biol 2005, 71:1-52.

49. Meiniel A: The secretory ependymal cells of the subcommissura organ: which role in hydrocephalus? Int J Biochem Cell Biol 2007, 39:463-468.

50. Picketts DJ: Neuropeptide signaling and hydrocephalus: SCO with the flow. J Clin Invest 2006, 116:1828-1832.

51. Somera KC, Jones HC: Reduced subcommissural organ glycoprotein immunoreactivity precedes aqueduct closure and ventricular dilatation in H-Tx rat hydrocephalus. Cell Tissue Res 2004, 315:361-373.

52. Caprile T, Hein S, Rodriguez S, Montecinos H, Rodriguez E: Reissner fiber binds and transports away monoamines present in the cerebrospinal fluid. Brain Res Mol Brain Res 2003, 110:177-192.

53. Somera $\mathrm{KC}$, Jones $\mathrm{H}$ : Subcommissural organ dysfunction in $\mathrm{H}-\mathrm{Tx}$ rats with early-onset hydrocephalus. Eur J Pediatr Surg 2002, 12(Suppl 1): S45-47.

54. Rodriguez E, Yulis CR: Subcommissural organ. Cellular, molecular, physiological, and pathological aspects: one hundred years of subcommissural organ research. Microsc Res Tech 2001, 52:459-460.

55. Salehi Z, Mashayekhi F: The role of cerebrospinal fluid on neural cell survival in the developing chick cerebral cortex: an in vivo study. Eur J Neurol 2006, 13:760-764.

56. Sankaranarayani R, Nalini A, Rao Laxmi T, Raju TR: Altered neuronal activities in the motor cortex with impaired motor performance in adult rats observed after infusion of cerebrospinal fluid from amyotrophic lateral sclerosis patients. Behav Brain Res 2010, 206:109-119.

57. Steinfeld R, Grapp M, Kraetzner R, Dreha-Kulaczewski S, Helms G, Dechent P, Wevers R, Grosso S, Gartner J: Folate receptor alpha defect causes cerebral folate transport deficiency: a treatable neurodegenerative disorder associated with disturbed myelin metabolism. Am J Hum Genet 2009, 85:354-363.

58. Parada C, Escola-Gil JC, Bueno D: Low-density lipoproteins from embryonic cerebrospinal fluid are required for neural differentiation. J Neurosci Res 2008, 86:2674-2684.

59. Juranek J, Fletcher JM, Hasan KM, Breier JI, Cirino PT, Pazo-Alvarez P Diaz JD, Ewing-Cobbs L, Dennis M, Papanicolaou AC: Neocortical reorganization in spina bifida. Neurolmage 2008, 40:1516-1522.

60. Bachy I, Kozyraki R, Wassef M: The particles of the embryonic cerebrospinal fluid: How could they influence brain development? Brain Res Bull 2008, 75:289-294.

61. Mercimek-Mahmutoglu S, Stockler-Ipsiroglu S: Cerebral folate deficiency and folinic acid treatment in hypomyelination with atrophy of the basal ganglia and cerebellum (H-ABC) syndrome. Tohoku J Exp Med 2007, 211:95-96. author reply 97.

62. y Valenzuelal Martinez-Pena, Carmona-Calero EM, Perez-Gonzalez H, Ormazabal-Ramos C, Fernandez-Rodriguez P, Gonzalez-Marrero I, Castaneyra-Perdomo A, Ferres-Torres R: Alterations of the cerebrospinal fluid proteins and subcommissural organ secretion in the arterial hypertension and ventricular dilatation. A study in SHR rats. Histol Histopathol 2006, 21:179-185.

63. Khwaja FW, Nolen JD, Mendrinos SE, Lewis MM, Olson JJ, Pohl J, Van Meir EG, Ritchie JC, Brat DJ: Proteomic analysis of cerebrospinal fluid discriminates malignant and nonmalignant disease of the central nervous system and identifies specific protein markers. Proteomics 2006, 6:6277-6287.

64. Huhmer AF, Biringer RG, Amato $H$, Fonteh AN, Harrington MG: Protein analysis in human cerebrospinal fluid: Physiological aspects, current progress and future challenges. Dis Markers 2006, 22:3-26.

65. Zhang J, Goodlett DR, Peskind ER, Quinn JF, Zhou Y, Wang Q, Pan C, Yi E, Eng J, Aebersold RH, Montine TJ: Quantitative proteomic analysis of age-related changes in human cerebrospinal fluid. Neurobiol Aging 2005, 26:207-227.

66. Yuan X, Desiderio DM: Proteomics analysis of human cerebrospinal fluid. J Chromatogr B Analyt Technol Biomed Life Sci 2005, 815: 179-189.

67. Dziegielewska KM, Knott GW, Saunders NR: The nature and composition of the internal environment of the developing brain. Cell Mol Neurobiol 2000, 20:41-56.

68. Johanson CE, Duncan JA 3rd, Klinge PM, Brinker T, Stopa EG Silverberg GD: Multiplicity of cerebrospinal fluid functions: New challenges in health and disease. Cerebrospinal Fluid Res 2008, 5:10.

69. Martin C, Bueno D, Alonso MI, Moro JA, Callejo S, Parada C, Martin P, Carnicero E, Gato A: FGF2 plays a key role in embryonic cerebrospinal fluid trophic properties over chick embryo neuroepithelial stem cells. Dev Biol 2006, 297:402-416.

70. Mashayekhi F, Azari M, Moghadam LM, Yazdankhah M, Naji M, Salehi $Z$ : Changes in cerebrospinal fluid nerve growth factor levels during chick embryonic development. J Clin Neurosci 2009, 16:1334-1337.

71. Mashayekhi F: Neural cell death is induced by neutralizing antibody to nerve growth factor: an in vivo study. Brain Dev 2008, 30: 112-117.

72. Gordon N: Cerebral folate deficiency. Dev Med Child Neurol 2009, 51:180-182

73. Ramaekers VT, Sequeira JM, Blau N, Quadros EV: A milk-free diet downregulates folate receptor autoimmunity in cerebral folate deficiency syndrome. Dev Med Child Neurol 2008, 50:346-352.

74. Ramaekers VT, Weis J, Sequeira JM, Quadros EV, Blau N: Mitochondrial complex I encephalomyopathy and cerebral 5methyltetrahydrofolate deficiency. Neuropediatrics 2007, 38:184-187.

75. Ramaekers VT, Sequeira JM, Artuch R, Blau N, Temudo T, Ormazabal A, Pineda M, Aracil A, Roelens F, Laccone F, Quadros EV: Folate receptor autoantibodies and spinal fluid 5-methyltetrahydrofolate deficiency in rett syndrome. Neuropediatrics 2007, 38:179-183.

76. Ramaekers VT, Blau N, Sequeira JM, Nassogne MC, Quadros EV: Folate receptor autoimmunity and cerebral folate deficiency in lowfunctioning autism with neurological deficits. Neuropediatrics 2007, $38: 276-281$

77. Koenig MK, Perez M, Rothenberg S, Butler IJ: Juvenile onset central nervous system folate deficiency and rheumatoid arthritis. J Child Neurol 2008, 23:106-107.

78. Pineda M, Ormazabal A, Lopez-Gallardo E, Nascimento A, Solano A, Herrero MD, Vilaseca MA, Briones P, Ibanez L, Montoya J, Artuch R: Cerebral folate deficiency and leukoencephalopathy caused by a mitochondrial DNA deletion. Ann Neurol 2006, 59:394-398.

79. Willemsen MA, Wevers RA, Verbeek MM: Cerebral folate deficiency syndrome. N Engl J Med 2005, 353:740. author reply.

80. Hansen FJ, Blau N: Cerebral folate deficiency: life-changing supplementation with folinic acid. Mol Genet Metab 2005, 84: 371-373.

81. Ramaekers VT, Blau N: Cerebral folate deficiency. Dev Med Child Neurol $2004,46: 843-851$

doi:10.1186/2045-8118-9-8

Cite this article as: Nabiuni et al:: In vitro effects of fetal rat cerebrospinal fluid on viability and neuronal differentiation of PC12 cells. Fluids and Barriers of the CNS 2012 9:8. 